\title{
Chapter 6 \\ Contested Water Governance in Myanmar/Burma: Politics, the Peace Negotiations and the Production of Scale
}

\author{
Johanna M. Götz
}

\subsection{Introduction}

It's a clear morning in early 2017. The sun has only come up a few hours ago, however, the heat of the day is already tangible. Villagers and activists from all over Myanmar/Burma, ${ }^{1}$ media representatives, Karen National Union (KNU) members and non-state armed forces peacefully gather on an island in the Salween/Thanlwin river in Karen State. They talk about the river's importance to the livelihood of communities and about its beauty. They express their rejection of the construction of mega-dams across it and discuss these dams' influences on conflict and peace building. Prayers and poems, discussions and talks, pictures and music try to capture the river in all its dimensions. A couple of days after the event, a letter arrives from the Karen State Government addressed to the KNU condemning this 'unauthorized' gathering. It criticizes the KNU, stating inter alia that they had infringed the agreements of the National Ceasefire Agreement (NCA), including Article 25(c) that states:

[...] government and the individual [...] Ethnic Armed Organizations shall coordinate the implementation of tasks that are specific to the areas of the respective Ethnic Armed Organization. (NCA 2015)

These criticisms are connected with the request towards the KNU to follow the NCA by controlling their armed members. What can this short insight tell about

\footnotetext{
${ }^{1}$ I use the terms Burma/Myanmar, and further names changed under the 2008 constitution, interchangeably. This is far from implying that naming is irrelevant. However, throughout a myriad of conversations, I realized that either term has its own limits. For now, I therefore choose to follow the advice of a colleague stating: "I think we have to move beyond that debate - there are more important issues at the moment."
}

Johanna M. Götz, Ph.D. Candidate, Department of Geography, University of Bonn \& Development Studies, University of Helsinki; Email: johanna.goetz@ helsinki.fi.

(C) The Author(s) 2019

C. Middleton and V. Lamb (eds.), Knowing the Salween River: Resource Politics

of a Contested Transboundary River, The Anthropocene: Politik-Economics-

Society—Science 27, https://doi.org/10.1007/978-3-319-77440-4_6 
water governance in Myanmar? Throughout this chapter, I demonstrate how the Salween River (cf. Fig. 6.1a: Myanmar's nation-state borders and the Salween River Basin) represents much more than just material water flowing downhill, and how the river is deeply embedded into a complex history and current socio-political struggles. Simultaneously, I show how highly contested power-relations play out in claims for decision-making around various scales, and its significance to the reshaping of water governance. To approach this, two substantial foci arise as fundamental conceptual frames for this chapter: (1) an understanding of water as hydrosocial (Linton/Budds 2014); and (2) how within that understanding the production of scale is historically embedded, highly political and socially contested. Overall, I show how the scales of water governance in Myanmar are currently being contested and argue that this constitutes a key battleground for future decision-making not only in terms of water governance, but also with implications for the peace negotiations and the federal structure of government that it is working towards.

Burma is at a unique historic moment as a key struggle over the future rules of water governance, and the role and relative influence of actors involved, is unfolding. With clear rules and laws around water yet to be established, different narratives, imaginaries, material practices on the ground and institutional arrangements around water governance become apparent. This becomes evident looking at two groups of actors with rather different visions: The National Water Resources Committee (NWRC) and its Advisory Group (AG) acting under the Union government, and a group of non-state actors connected to the Salween Peace Park (SPP) within the KNU-controlled, ethnic-minority dominated Mutraw District in Karen State. While at the Union level a rather centralized, expert-led water policy-making process is seeking to generate a unified Myanmar narrative, actors around the SPP propose a contrasting arena of community-led, bottom-up federalism.

This chapter builds on an explorative approach with qualitative interviews and informal conversations conducted in 2017 (Götz 2017). Actors consisted of informants connected to the NWRC (including: NWRC members, AG individuals) and the SPP (including: informants from local CSOs and the KNU; international supporters). ${ }^{2}$ The research is further supported through media and document analysis.

The chapter is organized as follows: First, I outline the conceptual frame of the chapter before providing some relevant background on Burma's socio-political history as it relates to current claims around the scales of water governance. Recent developments regarding the peace negotiations and the struggle over the degree of decentralization are also highlighted. Subsequently, the two groups of actors with their specific claims around future rules of water governance and its implications for the production of scale are introduced. Finally, I draw those claims together to explore the arenas and processes through which scale is being contested, before concluding on the implications for the future rules of water governance in Myanmar.

\footnotetext{
${ }^{2}$ To protect the informant's anonymity all informants quoted in this chapter are coded in accordance with one of the two key groups they are related to (i.e. NWRC or SPP).
} 
(a)

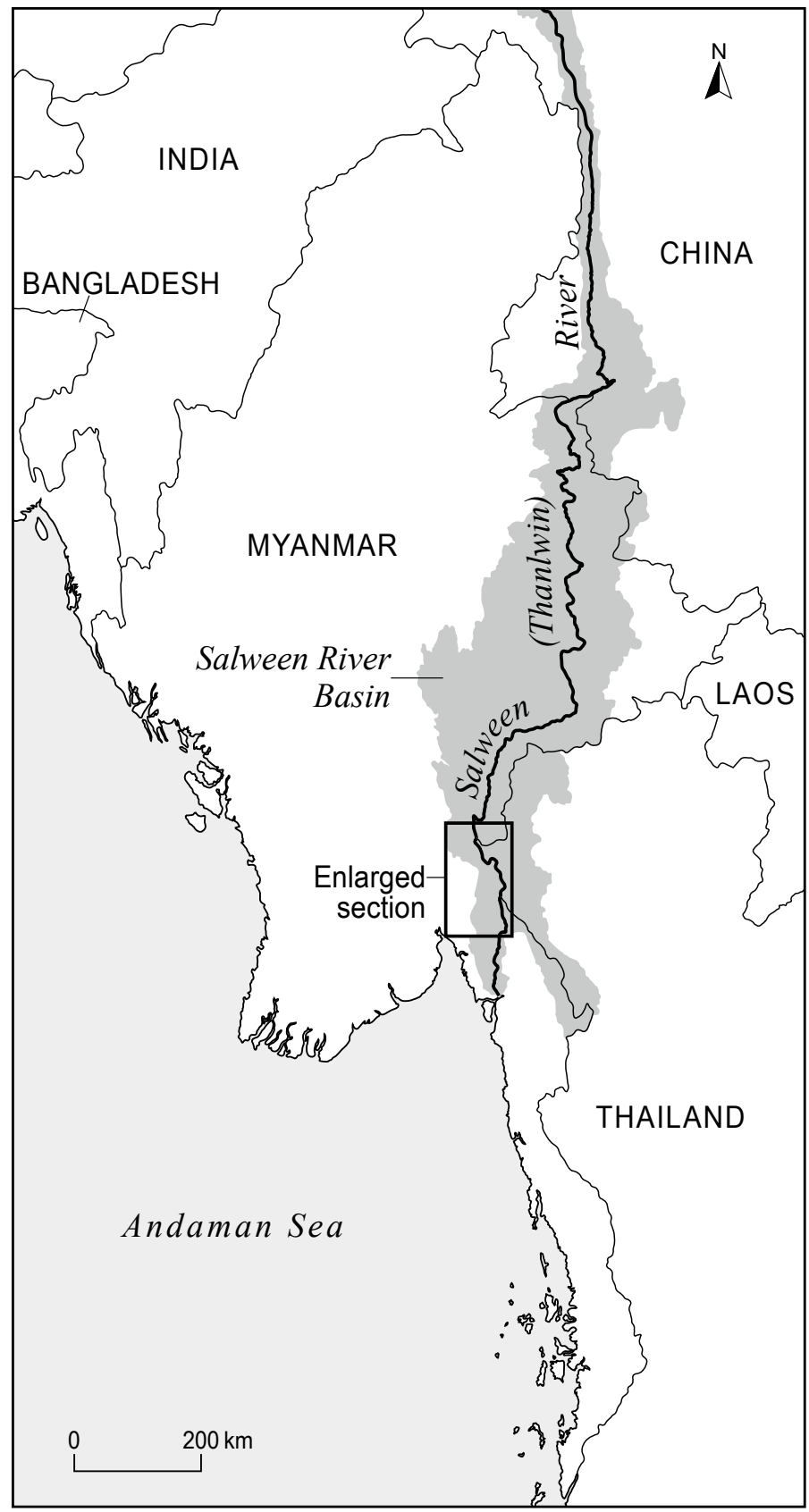

Fig. 6.1 Articulated scalar manifestations/ claims around water governance in Burma/ Myanmar. a Myanmar's nation-state borders and the Salween River Basin. b The Salween Peace Park within Karen State's/ Kawthoolei's Hpapun/ Mutraw District. Source Cartography by Chandra Jayasuriya, University of Melbourne, with permission 
(b)

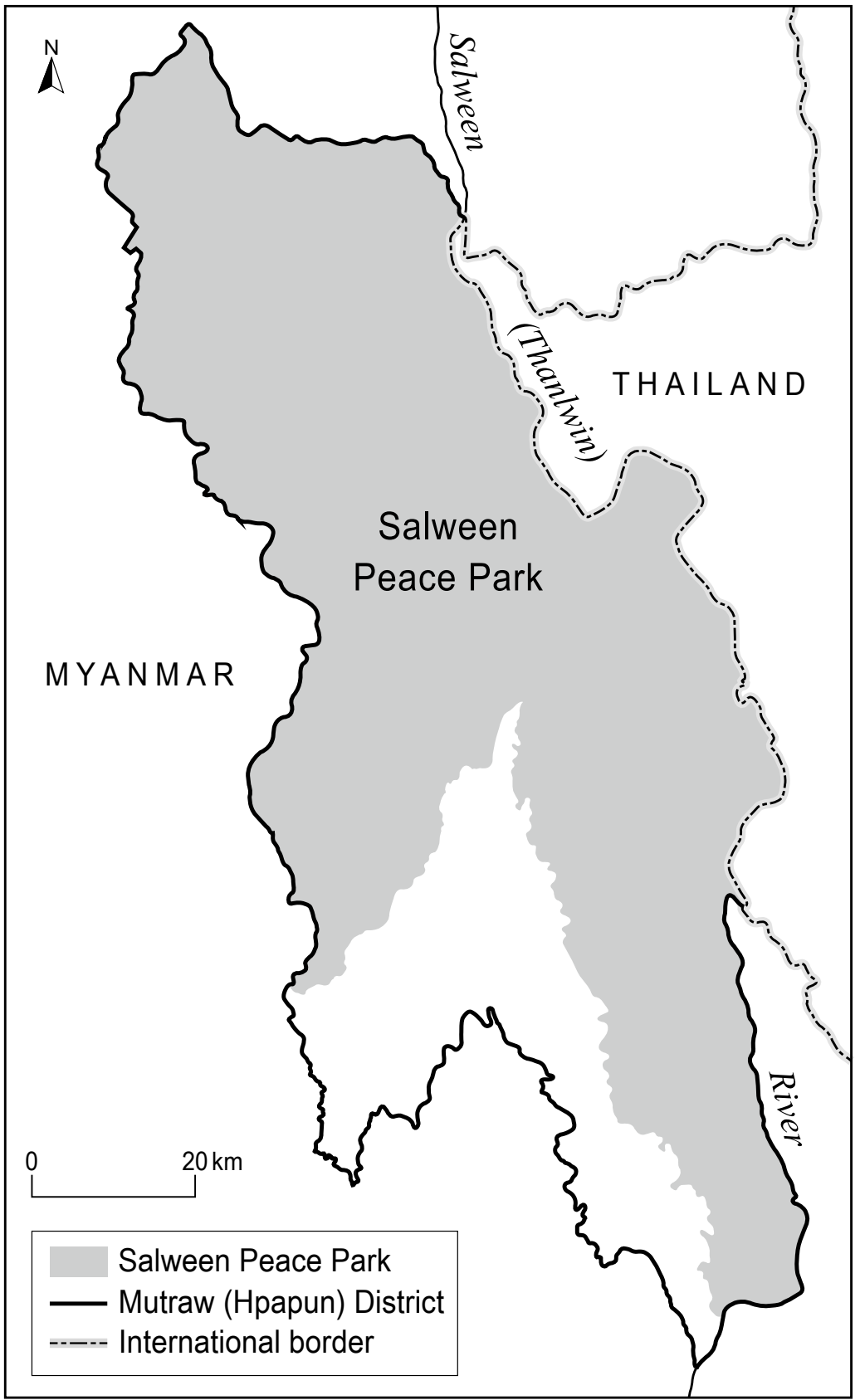

Fig. 6.1 (continued) 


\subsection{Water Through a Hydrosocial Lens and the Production of Scale}

Considering water from a hydrosocial perspective holds major implications for understanding water and water governance (e.g. Boelens et al. 2016; Linton/Budds 2014). Through a hydrosocial lens, water is seen not as a mere material "natural resource", but rather as a "historical and relational-dialectic process" (Linton/Budds 2013: 10) wherein water and society constantly constitute themselves as "socionatural hybrids (cf. ibid.; Linton 2010). Viewing water and society not as two dualistic entities but as "hybrid nature" (Budds/Hinojosa 2012) reveals how water and society evolve through one another and consequently, water governance is understood as more than institutions and policies, but reflects the wider array of co-constituting human and more-than-human relationships. This leads to the insight that "water is not politically neutral, but instead both reflects and reproduces relations of social power" (Perreault 2015: 118).

Scale as a concept has been subject of heated debates (e.g. Brenner 2001; Herod 2011; Neumann 2015). While some call for eliminating 'scale' as a concept (Marston et al. 2005), others show the relevance of it when applied critically (e.g. Leitner/Miller 2007). Critical research has sought to redefine scale away from understanding it as hierarchical, fixed and apolitical towards an understanding of scale as:

[...] something that is produced; a process that is always deeply heterogeneous, conflictual, and contested. Scale becomes the arena and moment, both discursively and materially, where sociospatial power relations are contested and compromises are negotiated and regulated. Scale, therefore, is both the result and the outcome of social struggle for power and control. (Swyngedouw 1997: 140)

Within this understanding, debates around water governance and the politics and production of scale have gained momentum (e.g. Dore/Lebel 2010; Norman et al. 2015). Within a hydrosocial understanding, scalar relations have been addressed through concepts like 'waterscapes' (Budds/Hinojosa 2012) or "hydrosocial territories" (Boelens et al. 2016). Drawing from these debates, I focus on the processes that influence the (re)construction of scalar notions (i.e. their continuous (re)production, contestation and reconfiguration) and (temporal) manifestations related to water in its socio-material dimensions rather than looking at scale per se.

Considering the widespread understanding of socially-constructed scales, within water policy-making it can be observed that certain scales are given priority, while downplaying or marginalizing less obvious scalar networks that influence water. Budds/Hinojosa (2012: 119) emphasize the importance of overcoming the still prevalent practice to "take the hierarchical physical boundaries and administrative structures that characterize most instances of water governance as given" and instead focus on the politics and production of scale. This becomes evident when looking at the widespread use of the watershed or river basin as the seemingly pre-given, most suitable scale for water policy-making. Since the 1990s, the old concept of river basin management gained new relevance and became the scale for water governance 
in "the West" (and subsequently far beyond) (Molle 2015; Warner et al. 2008). This is embedded in a notion of hydrological boundaries of the watershed, which is assumed to be a 'natural' scale for governing. However, in fact this assumption renders both scale and water as fixed, and thus stands in stark contrast with a hydrosocial understanding. While it is clear that hydrological flows - as water's materiality - exist and are indeed relevant, taking the scale of the river basin for granted does leave out important social, cultural and political dimensions. As Blomquist/Schlager (2005: 103-5) argue, choosing the watershed as the appropriate scale for water governance is always a conscious choice - rather than a 'natural' given necessity - that brings political momentum with it. Ultimately, defining a scale for water governance (be it the watershed, administrative boundaries or other envisioned or drawn spaces) brings with it questions about which actors are involved in decision-making, affected by it and how power is distributed. As such, it is not about neglecting material flows within hydrologically defined watersheds, but to avoid considering these flows as independent from other hydrosocial arrangements.

\subsection{Transforming Water Governance in Myanmar}

The production of scale around water governance and associated claims for power are, as I will argue, deeply embedded within a wider historical context. Under British colonialism, the borders of what is known as Myanmar today were defined for the first time. Included in it were the areas of Bamar-dominated "Burma Proper" under the centralized authority of the British, which covered the central low-lying areas. The more remote "Frontier Areas" in the hilly border regions, meanwhile, were inhabited by different non-Bamar ethnic minority groups and were under less rigorous authority by the British, thus "allowing traditional local leaders to run the day-to-day affairs" (Callahan 2007: 12). After independence, a short attempt to find a peaceful federal solution as written in the 1947 Constitution ended abruptly through Ne Win's coup in 1962. The decades to follow were characterized by centralized authoritarian regimes (Ninh/Arnold 2016). However, as Callahan (2007: 12-13) states, there have been areas that:

[t]hroughout the postcolonial era, $[\ldots]$ have never come under anything approaching central control. Large stretches of territory [...] and large numbers of people have been governed, administered, and exploited by armed state challengers, such as [...] the Karen National Union.

Recent economic and political reforms in Myanmar since 2010-11 have led to an increased liberalization of economic policy, attracting growing volumes of foreign investment. However, Burma remains unique in the region as it is in the state of a fragile (partial) ceasefire rather than peace. Within Myanmar's emerging political system of National and Regional/State governance, not formally represented non-state actors remain highly influential and are seeking strong localized federalism. The question remains open as to what a future federal system will look 
like (e.g. Ninh/Arnold 2016). Given that water is highly political, especially if understood from a hydrosocial perspective, then water governance in Burma must be positioned in this wider historical and political context. With the recent change from military dictatorship to a quasi-civilian government, clear rules and laws around water, or the scales of water governance, are yet to be established, which will, amongst other things, depend on the degree of decentralization under a future federal agreement.

After decades of military dictatorship and with it the oppression of most critical thinking, the nascent state of literature on water governance in Myanmar is unsurprising. ${ }^{3}$ However, there are a growing number of articles, reports and scholarly literature on water-related issues. This includes reports looking at the current water-related Union government institutions and respective legal frameworks (e.g. Kattelus et al. 2014; van Meel et al. 2014). While providing some key issues (lack of transparency; public participations), solutions are mainly proposed along the line of a globally hegemonic water management approach, namely Integrated Water Resources Management (IWRM). Thereby, most research taking a localized perspective raises a management approach rather than a hydrosocial perspective (ibid.). Alternative paradigms and framings of water are much less discussed in academic literature on water governance in Burma, with some notable exceptions (e.g. Middleton et al. 2017; Suhardiman et al. 2017).

Within the two subsequent sections, I aim to exemplify the importance of moving beyond a simplified understanding of water governance and emphasize the wider hydrosocial relations and their scalar politics. Figure 6.1: Articulated scalar manifestations/claims around water governance in Burma/Myanmar illustrates the examined articulated scalar manifestations and claims around water governance, including Fig. 6.1a: Myanmar's nation-state borders and the Salween River Basin, and Fig. 6.1b: The Salween Peace Park within Karen State's/Kawthoolei's Hpapun/ Mutraw District. While the visualization of this may carry political clout with it, the mappings illustrate the intertwined and overlapping scalar articulations, unveiling the complexity of the future rules of water governance in Burma.

\subsection{National Water Policy Regime}

With the transition towards a quasi-democratic government system, a major restructuring of state-based institutions has unfolded in Myanmar. This has been accompanied by new discourses and visions around the future-rules of water governance, which will influence how hydrosocial relations unfold. Under the presidential degree of U Thein Sein, a working group called the National Water Resources Committee (NWRC) was established in 2013 with the goal to "take responsibility for the overall management of national water resources and to

\footnotetext{
${ }^{3}$ This may not include sources in Burmese/other, ethnic-minority languages and unpublished work.
} 
facilitate for a more coordinated approach" (Nesheim et al. 2016: 21). After the dissolution of the committee at the end of U Thein Sein's presidential period in March 2016, the NWRC was reestablished by the new NLD-led government in June 2016 (personal communication, NWRC2).

The current NWRC and its Advisory Group (AG) includes a network of actors from water-related Union ministries, departments, representatives from the State and Regional level, the mayors of Yangon, Naypyidaw and Mandalay, and 'water experts' under the Chair of Vice President U Henry Van Thio. The NWRC Secretary is the Directorate of Water Resources and Improvement of River Systems (DWRI) of the Union Ministry of Transport and Communication (NWRC 2015, 2017). The makeup of the NWRC, with involved ministries amongst others including the Ministry of Industry, the Ministry of Electric Power and Energy, the Ministry of Agriculture, Livestock and Irrigation, and the Ministry of Natural Resources and Environmental Conservation, already hints towards the heterogenous interests existent within water-related decision-making. Reflecting the fragmented responsibilities across sectors and ministries, one objective of the NWRC is the "strengthening of inter-ministerial cooperation, communication and information sharing" (NWRC 2015, Art. 2.4(ii)).

A key mandate of the NWRC is to draft water-related rules and regulations. With the National Water Policy (NWP) first published in February 2014 (NWRC 2015) and approved by the cabinet in June 2015 (personal communications, NWRC1 and NWRC6) together with the National Water Framework Directive (NWFD), two documents have already been published while a National Water Law is currently being drafted but not publicly available at the time of writing (January 2019; See also, Bright, Chap. 5, this volume). This is meant to be an umbrella law for any water-related laws.

Key paradigms and concepts visible in the NWRC's work indicate a rather centralized, expert-led water-policy making that is shaping specific narratives around water in Burma. Rereading the analysis of Nesheim et al. (2016) on current institutional settings suggests that hegemonic global influences can be found in Myanmar's emerging policies. For instance, the NWFD does not only carry the name of but

[...] is inspired by the EU WFD [European Union Water Framework Directive] in that it parallels several of the same principles as those in the European directive, including among others River Basin Management. (ibid: 22)

However, in contrast to the EU WFD, it is not set to be a binding law, but is instead "an umbrella statement of general principles governing the exercise of legislative and/or executive (or devolved) powers by the Union, the States and Regions, and the local governing bodies" (van Meel et al. 2014: 12). IWRM is communicated as the central paradigm. The NWP clearly states this in various places, for example:

[T]here are inequities in distribution and lack of a unified perspective in planning, management and use of water resources, i.e. little or no knowledge about [IWRM] except in the domain of water professionals. The whole country needs to be aware of IWRM principles and participatory approach. (NWRC 2015: 2, emphasis added) 
With IWRM as a central paradigm, various water-related sectors are to be integrated' under the auspices of the NWRC as a powerful apex body. In so-called 'international best practice', IWRM has tended to go together with a call for the river basin as the appropriate level of governance (cf. Molle 2015). In Burma, a call for river basin management can be observed in the narrative of several government documents and actors, even though it is not formulated as the only level of governance:

All the elements of the water cycle [...] are interdependent and the basic hydrological unit is the river basin, which should be considered as the basic hydrological unit for planning.

(NWRC 2015: 15)

Ongoing projects further accelerate the focus on a combined IWRM approach at the river basin scale, such as the Ayeyarwady Integrated River Basin Management (AIRBM) project financed by the World Bank with the objective "to help Myanmar develop the institutions and tools needed to enable informed decision making in the management of Myanmar's water resources and to implement integrated river basin management of the Ayeyarwady Basin" (MoT 2017). It should, however, be emphasized that to date no transboundary river basin organizations or similar agreements exist for the country's rivers, even though some informants are proposing such institutionalizations (personal communication NWRC3, 2017). Rather, the 'natural' river basins seem to be bounded by the borders of the nation-state.

With this Union government-led decision of IWRM implementation at a river basin level for the whole country, as affirmed in the NWP and materialized in projects such as the AIRBM, the river basin as a specific scale for water governance is (consciously or not) being produced as an appropriate level for decision-making over water. Furthermore, by prescribing a hegemonic global concept at the level of seemingly 'natural' boundaries, IWRM is being raised as the appropriate basis for decision-making. This brings with it a centralizing tendency: this occurs strategically, by prescribing IWRM as an overall paradigm for the country from a Union level perspective. Thereby, other established water governance practices (e.g. customary rights) might be overwritten. It also occurs institutionally, by 'integrating' various institutions - with their distinct power relations - under the umbrella of water management whereby a (re)centralization of power through IWRM implementation has been predicted and observed in other contexts (e.g. Mehta et al. 2014). On paper, IWRM is supportive of decentralization thus intending to redistribute decision-making to 'lower' levels. For Burma, this would mean decentralization towards the Region or State governments. However, what sounds locally empowering in theory might prove to be centralizing in practice, as a lack of capacity and internal conflict at the Region/State level might redirect power back to the National level or to certain powerful factions (cf. Mehta et al. 2014 for a South African exploration). Moreover, current customary rights and established practices around water governance, as prevalent in some areas, would be overwritten by Union state-controlled IWRM practices. 
The above-mentioned centralizing tendency becomes further consolidated when examining national-level water policy actors who, besides the river basin, place a strong emphasis on the Union government and, with this, a centralized level of water governance.

The objective of the National Water Policy is to take cognizance of the existing situation, to propose a framework for creation of a system of laws and institutions and for a plan of action with a unified national perspective. (NWRC 2015, emphasis added)

[I]f the country is going to federalization and [...] if there is a region and region conflict of interest, there will be the national level coming in and decide. And also, if it is a national-level concern, like the national/international, transboundary river, then the national government is concerned [...]. So [the National Water Law] will be the master of all the laws related to water [...] and everything is to be integrated [...]. According to our Constitution, the right is under the [Union] state of handling water. (personal communication NWRC3, 2017, emphasis added)

While universal rights are underlined, the power of decision-making is clearly given to the central government (at least in the second instance). The NWRC has repeatedly been referred to as an important apex body for the water governance of Myanmar inter alia by its members (personal communications, 2017) and envisions a future influential role. The NWP further underpins this intended central position of the committee by stating:

[The] NWRC should be a legislative body in national water sector and should have authorization of the government to play a significant role in any national/state level water use $[\ldots]$ of consumptive or non-consumptive nature. (NWRC 2015: 46)

The centralization of power is also influenced by the relatively small number of individuals - namely a limited number of "water professionals" (personal communication NWRC1, 2017) - active within the central institutions.

The NWRC and its AG are a significant part of current efforts to pave the way for future water governance at a Union level by drafting policies and laws. However, in practice they still do not have the final say in whether those are adopted within the rather fragmented government arrangements of the country. At the same time, they further their claim to legitimacy through collaborating with actors like the World Bank in the AIRBM project and other International Financial Institutions (IFIs), NGOs and national governments (i.e. the Netherlands or Norway). Thus, relying on concepts with a hegemonic status can be seen as important legitimization of authority by the Union within a 'transnational network' (cf. Hensengerth 2015). Additionally, the NWRC has been rather successful in being visible thorough, for example, joint reports with partners which represent some of the little information that is available on water governance in Burma (e.g. van Meel et al. 2014 on IWRM). Yet, some civil society actors repeatedly challenge the Union government's cooperation with actors like the World Bank and question the degree of participation in associated projects.

Historically-grown power relations in the central Bamar-majority area are reflected in today's centralizing tendencies both institutionally and materially (e.g. within the AIRBM project). Under colonial rule, this centralized control proved true 
for "Burma Proper" while the "Frontier Areas" were administered indirectly. After independence, little changed in those highly centralized power relations (Ninh/ Arnold 2016: 225-6). Simultaneously, however, as Callahan (2007: 12-13) notes, the following authoritarian regimes were at no time able to bring the whole country under central control. Rather, different Ethnic Armed Organizations (EAOs) set up their own 'state-like structures' and governance. Questions around decentralization and federalism date back to the post-colonial era and remain unresolved. While decentralization seems to be a rather universal goal, the degree of power redistribution remains one of the most crucial questions towards federalism in the current peace negotiation process (Ninh/Arnold 2016: 226). Decentralization - currently bound to the 2008 constitution - will create new scales of governance and redefine power relations, which also holds implications for water governance. While the NWRC seems to support decentralization of water governance, for now it claims and affirms its leadership role as an apex body:

Federal States should take charges for water governance and decision making around water in their state. But, for the early years they should [be] under the umbrella of Control Government body like NWRC. (personal communication NWRC5, 2017)

Concluding, it can be claimed that through rather centralized, expert-led water policy-making a national-state-scaled water policy narrative framed in a river basin-scaled unit of governance is currently emerging. These spatiotemporal notions - built around a hegemonic, unified Myanmar narrative on water governance - reflect historically-grown power relations and highlight the hydrosocial relations within which water and society constantly (re)produce themselves (cf. Linton/Budds 2014).

\subsection{Salween Peace Park: A Local Initiative}

The recently officially proclaimed Salween Peace Park (SPP) (e.g. KESAN 2019), located in Mutraw District in Northern Karen State (Fig. 6.1b: The Salween Peace Park within Karen State's/Kawthoolei's Hpapun/Mutraw District), poses a quite different arena of governing water. A group of actors including community representatives, KNU local leadership, and members of CSOs push for their own vision within an area of over $5,000 \mathrm{~km}^{2}$, which encloses a range of 'community' and reserved forests, wildlife sanctuaries and customary land (KNU and KESAN 2016; personal communications, 2017). These actors envision

[a] grassroots, people-centered alternative to the previous Myanmar government and foreign companies' plans for destructive development in the Salween River basin. Instead of massive dams on the Salween River, we see small hydropower and decentralized solar power $[\ldots]$. Instead of megaprojects that threaten conflict and perhaps the resumption of war, we seek a lasting peace and a thriving ecosystem where people live in harmony with the nature around them. (KNU/KESAN 2016: 3) 
Based on these visions, a clear narrative becomes prevalent that calls for a "bottom-up", "community-based" approach with traditional systems to be preserved and promoted. Thereby 'local' people shall have "the right to self-governance", natural resources and wildlife shall be protected, and "Karen indigenous people's culture and life" are to be preserved (personal communication SPP3, 2017). In contrast to 'traditional' conservation areas, which tend to relocate people outside of the area, the SPP is claimed as integrating communities into it. One involved individual argues that there are many connecting

...issues that need to be considered when we talk about water governance and water management issues, because water is very political. Water is life, and everybody uses water every day. (Personal communication SPP1, 2017)

Here, a considerably different narrative of water that is more overtly stated as political is voiced out, which is also antagonistic vis-à-vis the rather centralized views described above. As the recently released SPP Charter (SPP Steering Committee/KNU 2018) demonstrates, a strong focus is placed on the 'community' as a central scale for decision-making. Connected to 'natural' ecosystems - for instance "community forests" - this scale can be, analogous to the watershed, understood as a naturalized social scale with the 'community' being handled as seemingly given entity and scale (cf. Cohen/McCarthy 2014). Nevertheless, the SPP Charter recognizes that "the Salween River is a precious resource that sustains the indigenous Karen people's way of life, and people who live beyond the boundaries of the Salween Peace Park" (SPP Steering Committee/KNU 2018: 30), recognizing the fluid character of water and the wider hydrosocial network beyond the borders of the SPP.

Spatially the SPP is based on historically-rooted power relations. It is within this historic context that the proposed borders of the SPP and therewith the envisioned scales of water governance are actively co-produced. The British colonial rule brought with it some major implications for power-relations within Myanmar. The "Frontier areas" included a small area of today's Karen State, namely the so-called Salween District. As part of these historically more autonomous areas, today's Mutraw District - while far from uncontested - up to this day "[...] remains the most autonomous KNU-controlled region and has never been brought under centralized state rule" (Jolliffe 2016: 9).

After independence, power-relations shifted several times not only between the $\mathrm{KNU}$ and Union government, but also amongst different KNU districts (Brenner 2017). During the 1990s, Mutraw District under Brigade 5 gained power relative to other districts due to declining economic trade with Thailand and strong interventions by Myanmar's armed forces. Power struggles at this time, according to Brenner (2017), led to today's factions within the KNU. The proposed SPP is located exactly in this still very much autonomous region, covering a majority of today's Mutraw District. Although the historic context can merely be touched upon, it already shows that the extent of today's SPP is anything but coincidental. Historically grown power-relations (re)shaped specific spaces and enable claim-making for future envisioned scales. 
In order to legitimize explicit visions of the SPP, different strategies can be observed. These include reinforcing the visions and scalar politics of the SPP by raising public awareness inter alia by initiating debates and campaigning through protests and media releases (cf. Dore/Lebel 2010 for similar strategies in the Mekong). Solidarity with other ethnic minority communities also connects the SPP to wider networks within and beyond Myanmar. Furthermore, actors working to further the SPP engage in protests against mega-dam development and thereby connect to a network of a localized - but also global - anti-dam movement (e.g. SSN et al. 2017). A range of articles, short documentaries and meetings further campaign for the idea of the SPP contributing to the contestation and production of scale (e.g. KESAN 2017).

Another way of consolidating claims to the right to govern are formalized in KNU policies related to "natural resources governance" (i.e. land and forest policy). The comprehensive KNU Land Policy was first ratified in 1974 (KNU 2015) and most recently revised in May 2016 (TBC 2016). While the KNU is also planning on its own water policy (Personal communications SPP1 and SPP2, 2017), the KNU Land Policy also already includes clear visions about water governance, stating for instance

The ethnic nationalities are the ultimate owners of all lands, forests, water, water enterprises and natural resources. (KNU 2015: 5)

This stands in direct contrast to the 2008 Constitution which defines the Union as "the ultimate owner of all lands and all natural resources above and below the ground, above and beneath the water and in the atmosphere in the Union" (Union of Myanmar 2008: 10).

The existence of autonomous laws within KNU-controlled areas represents a clear call for self-determination and different realities of current and future power structures:

This is KNU-controlled area, the Government is not able to come and set up their administration. KNU has its administration, [...and] operations, KNU collects taxes, KNU, even though they are not able to provide services, but in some way, they protect the people in their controlled territories, so the people believe and trust them [...]. And we are still in the $[\ldots]$ stage of negotiation with the Government that 'you have to recognize our policies and laws (and) administrations (while) we recognize your administration'. (Personal communication SPP1, 2017)

Hong (2017) within a legal pluralism frame looks at those "autonomous laws" within Burma and how the creation of law - may it be drafted by the state or, as in the case of the KNU, by an ethnic de-facto government - not only tries to consolidate power of the relevant actors, but through it contributes to the reshaping of scales. Referring to the KNU Land Policy, Hong (2017: 11) shows how law may serve "as a multi-scalar multi-temporal connecting tissue between the practice of autonomy in the here and now, and a long-term desire for self-determination and recognition." Looking at the SPP shows how scalar claims are being voiced out and how those are always closely connected to other (materialized/envisioned) scalar articulations - as with the land of the Karen people: Kawthoolei. 
However, it is important to recognize that a unified, self-determined Kawthoolei is not self-evident. In early 2017, elections were held to vote for the new KNU central government. Power-relations shifted heavily towards Saw Mutu Say Po's faction, pushing aside the opposition under Naw Zipporah Sein. While the former is known to be rather pro-business and open to the NCA and adjoining processes in their current form, the latter tends to be more nationalistic and has its strongest support within autonomous areas such as Mutraw District (Jolliffe 2017). While striving for peace is omnipresent, the ways of achieving it vary greatly, ${ }^{4}$ and the ideas around peace and (water) governance represented in the SPP are not feasible for all KNU-influenced territories. This is especially true as visions range from 'pro-development' to "conservation of traditional ways of life" (Jolliffe 2016). How 'appropriate' arrangements of governance will look like, are, however, up for debate, bringing the focus back to the heart of the scale debate and its highly political notion. Because, as Jolliffe (2017: n.p.) states, while Mutraw District oversees one of "the most powerful and well-supported KNU military units [, it has] barely been engaged in negotiations in the peace process so far." This limited representation might further fuel the SPP's narrative of the 'right' level of decision-making with a clear stance against any centralized approach of water governance.

The degree of power held by the central KNU administration seems to be at least twofold. Firstly, it seems to serve as a source of legitimization to get official recognition

So, to make sure this [(SPP charter)] is official, we need to bring that document to the KNU decision-makers, to make sure it is a kind of official document, an official regulation, official policy to rule the Peace Park. (Personal communication SPP2, 2017)

Secondly, one informant emphasized that "it's not that the KNU central is establishing [the SPP] at the KNU level", rather "the local people, they're the ones who are working to establish the Salween Peace Park" in a process that is happening "gradually, from the bottom up". Concluding that, as it is being established, it is "then eventually going up [...] to get recognized at the central [KNU] level" (personal communication SPP3, 2017). As such, internal power relations and their contestation become revealed.

Talking to one informant involved in the SPP about the national water law currently being drafted, it becomes quite evident that a more or less centralized national scale is not being recognized:

No, [the National Water Law would not have any influence within the SPP area] because the Salween Peace Park, as we say, is a demonstration to self-determination. It is not about the Union Government saying, 'you have to do this and that' - it's independent. As this is exactly what we are calling for: the right to self-determination. (Personal communication SPP2, 2017)

\footnotetext{
${ }^{4}$ This has become evidence once again in the recent (temporary) suspension of the KNU from the peace negotiations, demonstrating discrepancies both within the KNU and in relation to the central government.
} 
With this call for self-determination, the scalar visions around the SPP emphasize local values of water and the right of local uses to benefit. To sum up, it can be argued that a narrative of a more localized arena of community-led, bottom-up decision-making within a federalism of self-determination can be observed.

\subsection{Contesting Scale: A Battleground of Water Governance in Burma}

As laid out in the previous sections, water governance in Myanmar is far from being undisputed or apolitical, but rather reveals a battleground around different scales at which water is to be decided upon in the future. This chapter represents only a small fraction of claims available. Nevertheless, it shows the significance of looking beyond both a naturalized understanding of water as well as an oversimplification of 'appropriate' scales of water policy-making. Following an understanding of scale as being hydrosocially produced inevitably opens up questions around actors involved in (re)producing scales of water governance.

The sections above took a closer look at two sets of key actors, namely the NWRC and its AG, which can be seen to represent a centralized, national scale under the Union government, and KNU members, CSOs, and activists closely related to the SPP in Mutraw District, Karen State as one example of a more localized approach to water governance. Interestingly, both set of actors legitimized their respective claims by "rescaling to ecosystem spaces" (e.g. watershed or community forest) and "rescaling to jurisdictional scales" (e.g. States/Regions under the Union or Kawthoolei under a strong KNU and SPP) (Cohen/McCarthy 2014: 19). Figure 6.1: Articulated scalar manifestations/claims around water governance in Burma/Myanmar exemplifies these intertwined and overlapping scalar projects. Those groups of actors are only two among many intersecting networks contesting scales of water governance and the observed scalar claims are just an extract of many interconnected and overlaying visions out there. However, it becomes evident by introducing those two different networks of actors that diverse visions and paradigms around water governance exist, which aim at different scalar articulations at which decisions are to be made at.

Regarding how scales are being produced, different strategies are evident. Amongst them are legal strategies of actors drafting their own respective policies under differently recognized institutional arrangements and power-relations (i.e. NWRC vs. KNU/SPP) that are to regulate specific arenas (nation-state vs. Kawthoolei). While the NWRC aims at integrating the various claims and actors related to water governance on a unified Myanmar scale, the actors around the SPP are instead focusing on their own regulations at more localized scales. Thereby, the seemingly 'fixed' national scale is being contested.

To support their claims, both groups draw on different concepts that connect them to different local, national and transnational networks (cf. Boelens et al. 2016; 
Hensengerth 2015). With its claim for IWRM and its implication for water governance at the river basin, the NWRC and its AG focus on a dominant concept recognized by other governments, IFIs and INGOs. In contrast, while Peace Parks are also an internationally recognized concept, the actors around the SPP distance themselves from a pure conservationist approach and instead focus on communitybased decision-making with rather strong 'indigenous' notions (e.g. "Karen traditional lifestyle") thus relating themselves to a network of national and international non-state actors as grassroots activist and CSOs. They also engage in wider protests against mega-dam development and, with it, against centralized infrastructure construction conducted by state-related actors (IFIs, global investors, etc.). Discursively, actors draw their own specific visions and "scalar narratives" (Swyngedouw 1997: 140), legitimizing respective ideas about the 'right' scales of decision-making around water. Intending to communicate (largely) within their respective networks both sets of actors increase their visibility by releasing documentation on their envisioned scales (i.e. rather techno-scientific reports vs. politicizing press releases), both at times supported by maps of the contested scales (e.g. van Meel et al. 2014 or KNU/KESAN 2016). Looking at the proposed scales for future rules of water governance within a hydrosocial framing - while considering the highly political dimension water carries - puts the current peace negotiation process at the very heart of the debate. Claims around the appropriate scale for water governance closely connect to wider claims around decentralization and federalism, which will inevitably produce new scales at which decisions will be made at, and with it the forms of power (re)distribution. This contestation emphasizes current politics of scale

\footnotetext{
We are considering for governance and management of water resources in [a] federal system, but to form this system [...] depend[s mainly] on the political change and the changes of the governance system. Without having federal states and regions, it is impossible to have federal system for Myanmar's water [governance]. (Personal communication NWRC6, 2017)
}

The new Myanmar government has promised to lead the country toward a devolved, federal democracy. The Karen are not waiting idly for this: the Salween Peace Park is federal democracy in action. (KNU/KESAN 2016: 3)

The purpose of claiming certain scales for water governance for all informants seems to be a genuine will to reach some sort of "change for the better." How that change is to look like, however, differs tremendously. Different framings depending on varying priorities and goals - then have an influence on how scale is understood, constituted and (re)produced (cf. Sneddon/Fox 2012). Underlying power-relations will contribute significantly in defining which visions will prevail.

Although the enormous power of the Union government as an actor should not be neglected, the complexity of power relations in Burma should not be disregarded either. The NWRC consists of members from the Union government and is backed by it and a range of international players, but does not have unlimited authority. The SPP arena is located in an autonomous region where, up to this day, the Union government has limited influence. This autonomy tries to be maintained in a time of 
radical political change through repeated calls for self-determination. In turn, the SPP is also connected to a wider network of actors supporting their claims and thereby strengthens their proposed scales for future decision-making around water.

\subsection{Towards Future Rules of Water Governance}

Let us move back to the introductory incident around the Salween River. I will highlight how, by moving beyond a simplified understanding of water as an apolitical resource to be managed, towards emphasizing the wider array of co-constituting human and more-than-human spatiotemporal relationships, the contested water governance in Myanmar gets illuminated. As such, water is ultimately bound to wider, historically-grown processes and power-relations as visible within the ongoing peace negotiations. Looking at different networks of actors within the hydrosocial arena of Burma, I have argued that the production of scale is currently being contested and constitutes an important battleground about the future rules of decision-making and the actors involved in it, as well as the power relations within the wider network of actors. Scales are not a priori given - neither as a centralized Union state with hierarchal scales nor as independent localized factions evolving around the 'community' - but are subject to continuous contestation.

Understanding scalar articulations as intertwined and overlapping with other scalar imaginations and manifestations, as present along the Salween, brings to the fore the complex hydrosocial relations. This is apparent when considering how the envisioned SPP both connects and opposes a range of other scalar articulations: as part of the land of the Karen - Kawthoolei - and as such connects to KNU-based ways of organization; or simultaneously, as located in the 'official' administrative demarcation of Karen State which are to underlie the Union-based water governance paradigms. In addition, the SPP is part of the Salween River basin, both bound by the nation-state borders and as a transboundary river that connects to neighboring China and Thailand. Similarly, the NWRC is ultimately bound to the nation-state's (internal and external) boundaries, but simultaneously favoring international hegemonic IWRM and the river basin scale with its 'ignorance' to socially constructed borders. These represent just a few of the multiple overlapping scalar articulations, structured by certain rules and normative frameworks, embedded in wider hydrosocial networks, and subject to distinct power relations.

Political authority in Myanmar, and in particular in the Salween basin, is highly fragmented with intensely contested political power-relations, which are built on complex historical accounts (e.g. Callahan 2007). Looking at Myanmar's current politics, the degree of decentralization is highly controversial with a clear unified vision lacking. This further complicates questions about the future rules of water governance. Even with federalism established and institutional structures changed, decentralization processes do not automatically redistribute power-relations or empower local actors, as demonstrated in other contexts (e.g. Marks/Lebel 2016; Norman/Bakker 2009). Looking at the "incomplete decentralization" (Marks/Lebel 
2016) in neighboring Thailand shows how the degree of power redistribution is dependent on much more than an institutional restructuring. Within an arena of an emerging political system of National and Regional/State governance, as well as existing grey areas with quasi-/non-state actors seeking self-determination under a strong federalism, rules and regulations around water are yet to be (re)established with claims on the 'appropriate' scales being made by a range of actors with their respective narratives. Within such an understanding, the politics of scale constitutes a key battleground around which water governance is currently being (re)defined.

Acknowledgements My uttermost gratitude goes to my informants for their time and trust. I further thank the editors for all their work while compiling this volume; the HBF-Team, Yangon for their continued assistance; and everyone supporting my Master thesis process upon which this chapter draws - they know.

\section{References}

Blomquist, W., \& Schlager, E. (2005). Political pitfalls of integrated watershed management. Society \& Natural Resources, 18(2), 101-117.

Boelens, R., Hoogesteger J., Swyngedouw E., Vos, J., \& Wester, P. (2016). Hydrosocial territories: A political ecology perspective. Water International, 41(1), 1-14.

Brenner, D. (2017). Inside the Karen insurgency: Explaining conflict and conciliation in Myanmar's changing borderlands. Asian Security, 14(2), 1-17.

Brenner, N. (2001). The limits to scale? Methodological reflections of scalar structuration. Progress in Human Geography, 24(4), 591-614.

Bright, J. (2016). Rights and rites for water justice: A case study for the proposed Hatgyi Dam on the Salween river. In Center for Social Development Studies, the Mekong Sub-region Social Research Center \& Vietnam Academy of Water Resources (Eds.), Mekong, Salween and Red Rivers: Sharing knowledge and perspectives across borders (pp. 732-765). Bangkok, Thailand.

Budds, J., \& Hinojosa, L. (2012). Restructuring and rescaling water governance in mining contexts: The co-production of waterscapes in Peru. Water Alternatives, 5(1), 119-137.

Callahan, M.P. (2007). Political authority in Burma's ethnic minority states: Devolution, occupation, and coexistence. Washington, DC: East-West Center.

Cohen, A., \& McCarthy, J. (2014). Reviewing rescaling. Progress in Human Geography, 39(1), $3-25$.

Dore, J., \& Lebel, L. (2010). Deliberation and scale in Mekong region water governance. Environmental Management, 46, 60-80.

Götz, J. (2017). The politics of water governance in Myanmar - a hydrosocial approach. (Unpublished Masters thesis), University of Bonn, Germany.

Hensengerth, O. (2015). Where is the power?: Transnational networks, authority and the dispute over the Xayaburi Dam on the Lower Mekong Mainstream. Water International, 40(5-6), 911-928.

Herod, A. (2011). Scale. London, United Kingdom: Routledge.

Hong, E. (2017). Scaling struggles over land and law: Autonomy, investment, and interlegality in Myanmar's borderlands. Geoforum, 82, 225-236.

Jolliffe, K. (2016). Ceasefires, governance and development: The Karen National Union in times of change. The Asia Foundation.

Jolliffe, K. (2017, April 26). A new chapter for the Karen movement. Frontier Myanmar. Retrieved from: https://frontiermyanmar.net/en/a-new-chapter-for-the-karen-movement. 
Kattelus, M., Rahaman, M.M., \& Varis, O. (2014). Myanmar under reform: Emerging pressures on water, energy and food security. Natural Resources Forum, 38(2):85-98.

KESAN (Karen Environmental and Social Action Network). (2017). The Salween Peace Park: A place for all living things to share peacefully.

KESAN. (2019). Celebrating the Salween Peace Park proclamation. Retrieved from: http://kesan. asia/celebrating-the-salween-peace-park-proclamation/.

KNU (Karen National Union). (2015). Karen National Union - KNU Land Policy.

KNU (Karen National Union)., \& Karen Environmental and Social Action Network (KESAN). (2016). Salween Peace Park: A vision for an indigenous Karen landscape of human-nature harmony in southeast Myanmar. Yangon, Myanmar: KNU and KESAN.

Leitner, H., \& Miller, B. (2007). Scale and the limitations of ontological debate: A commentary on Marston, Jones and Woodward. Transactions of the Institute of British Geographers, 32 (1):116-125.

Linton, J. (2010). What is water? The history of a modern abstraction (1st ed). Vancouver, Canada: UBC Press.

Linton, J., \& Budds, J. (2014). The hydrosocial cycle: Defining and mobilizing a relational-dialectical approach to water. Geoforum, 57, 170-180.

Marks, D., \& Lebel, L. (2016). Disaster governance and the scalar politics of incomplete decentralization: Fragmented and contested responses to the 2011 floods in Central Thailand. Habitat International, 52, 57-66.

Marston, S., Jones, J.P., \& Woodward, K. (2005). Human geography without scale. Transactions of the Institute of British Geographers, 30(4), 416-432.

Mehta, L., Alba, R., Bolding, A., Denby, K., Derman, B., Hove, T., Manzungu, E., Movik, S., Prabhakaran, P., \& Van Koppen, B. (2014). The politics of IWRM in southern Africa. International Journal of Water Resources Development, 30(3), 528-542.

Middleton, C., Thabchumpon, T., Lian, V.B., \& Pratomlek, O. (2017). Water governance and access to water in Hakha Town, Chin State, Myanmar: Towards addressing water insecurity: Bangkok.

Ministry of Transport and Communication (MoT). (2017). Ayeyarwady Integrated River Basin Management (AIRBM) Project. Retrieved from: https://www.airbm.org/.

Molle, F. (2015). Examining scalar assumptions: Unpacking the watershed. In E. S. Norman, C. Cook, \& A. Cohen (Eds.), Negotiating water governance (pp. 17-24). London and New York: Ashgate.

National Water Resources Committee (NWRC). (2015). Myanmar National Water Policy: NWP.

National Water Resources Committee (NWRC). (2017). National Water Resources Committee: Overview and activities 2016-2017.

Nationwide Ceasefire Agreement (NCA). (2015). The Nationwide Ceasefire Agreement between the Government of the Republic of the Union of Myanmar and the Ethnic Armed Organizations.

Nesheim, I., Wathne, B.M., \& Tun, Z.L. (2016). Myanmar: Pilot introducing the National Water Framework Directive. Water Solutions, 1, 18-28.

Neumann, R.P. (2015). Political ecology of scale. In R.L Bryant (Ed.), The international handbook of political ecology (pp. 475-486). Cheltenham, United Kingdom: Edward Elgar Publishing.

Ninh, K.N.B., \& Arnold, M. (2016). Decentralization in Myanmar: A nascent and evolving Process. Journal of Southeast Asian Economics, 33(2), 224-241.

Norman, E.S., \& Bakker, K. (2009). Transgressing scales: Water governance across the Canada-U. S. borderland. Annals of the Association of American Geographers, 99(1), 99-117.

Norman, E.S, Cook. C., \& Cohen, A. (Eds.). (2015). Negotiating water governance: Why the politics of scale matter. London and New York: Ashgate.

Perreault, T. (2015). Beyond the watershed: Rescaling decision-making: Introduction to part II. In E.S, Norman, C. Cook \& A. Cohen (Eds.), Negotiating water governance (pp. 117-124). London and New York: Ashgate. 
Save the Salween Network (SSN), Burma Rivers Network (BRN), Burma Environmental Working Group (BEWG). (2017). Countrywide gatherings on International Rivers Day to oppose large dams in Burma's conflict zones.

Sneddon, C., \& Fox, C. (2012). Water, geopolitics and economic development in the conceptualization of a region. Eurasian Geography and Economics, 53(1), 143-160.

SPP Steering Committee, Karen National Union (KNU). (2018). Charter of the Salween Peace Park.

Suhardiman, D., Rutherford J., \& Bright, J. (2017). Putting violent armed conflict in the center of the Salween hydropower debates. Critical Asian Studies, 3(4), 1-16.

Swyngedouw, E. (1997). Neither global nor local: 'Glocalization' and the politics of scale. In K.R Cox (Ed.), Spaces of globalization (pp. 137-166). New York and London: Guilford Press.

The Border Consortium (TBC). (2016). KNU recognizes rights to land restitution for displaced communities. Retrieved from: http://www.theborderconsortium.org/news/knu-land-policy/.

Union of Myanmar. (2008). The Constitution of the Republic of the Union of Myanmar.

van Meel, P., Leewis, M., Tonneijck, M., Leushuis, M., de Groot, K., de Jongh, I., Laboyrie, H., Graas, S., Shubber, Z., Klink, T., Douma, D., \& Nauta, T. (2014). Myanmar integrated water resources managements. Strategic study: Research and analysis, strategies and measures.

Warner, J., Wester, P., \& Bolding, A. (2008). Going with the flow: River basins as the natural units for water management? Water Policy, 10(S2), 121.

Open Access This chapter is licensed under the terms of the Creative Commons Attribution 4.0 International License (http://creativecommons.org/licenses/by/4.0/), which permits use, sharing, adaptation, distribution and reproduction in any medium or format, as long as you give appropriate credit to the original author(s) and the source, provide a link to the Creative Commons license and indicate if changes were made.

The images or other third party material in this chapter are included in the chapter's Creative Commons license, unless indicated otherwise in a credit line to the material. If material is not included in the chapter's Creative Commons license and your intended use is not permitted by statutory regulation or exceeds the permitted use, you will need to obtain permission directly from the copyright holder. 